\title{
Testing pecking order prediction from the viewpoint of managerial optimism: Some empirical evidence from Taiwan ${ }^{2}$
}

\author{
Yueh-hsiang Lin ${ }^{\mathrm{a}, *}$, Shing-yang $\mathrm{Hu}^{\mathrm{b}}$, Ming-shen Chen ${ }^{\mathrm{b}}$ \\ ${ }^{a}$ Department of Banking and Finance, Takming College No. 56, Sec. 1, Huanshan Road, \\ Neihu District, Taipei, 11451, Taiwan \\ b Department of Finance, National Taiwan University, Taiwan
}

Available online 4 May 2007

\begin{abstract}
In this paper we examine the relation between managerial optimism and corporate financing decisions by empirically testing Heaton's [Heaton, J., 2002, Managerial optimism and corporate finance, Financial Management 31, 33-45.] model. Heaton showed that, besides information asymmetry, managerial optimism can also lead to pecking order preference in financing decisions. We test whether pecking order preference performs better when managers are more optimistic. Our measure of managerial optimism is constructed from management earnings forecasts. Managers are more likely to issue forecasts that are higher than the realized earnings when they are optimistic in their assessment of future outcomes. Using listed Taiwanese companies as our sample, we find that optimistic CEOs exhibit a stronger relation between debt issue and financing deficit, when compared with non-optimistic ones. These findings are consistent with the predictions of Heaton's model.
\end{abstract}

(C) 2007 Elsevier B.V. All rights reserved.

JEL classification: G32

Keywords: Financing decisions; Managerial optimism; Management earnings forecasts; Pecking order theory

\footnotetext{
We would like to thank the editors, Kenneth Kim and John Nofsinger, and the two anonymous referees of this journal for their helpful suggestions. We would also like to thank Sheng-Syan Chen, Yuanchan Chang, Konan Chan, Hung-Jen Wang, Anchor Lin, Chun An Li, Antti Pirjettä, seminar participants at the National Taiwan University, and the 2005 Contemporary Issues on Finance, the 2006 European Financial Management Symposium, and the annual meeting of the Taiwan Finance Association for helpful comments. Chen acknowledges the financial support from the National Science Council (94-2416-H-002-045).

* Corresponding author. Tel.: +886 226585801 \#5103; fax: +8862 26582507.

E-mail address: nelsonlin@takming.edu.tw (Y. Lin).
} 


\section{Introduction}

The pecking order theory of financing decisions is one of the most well-known theories of corporate finance. Pioneered by Myers (1984), pecking order refers to managers' preferences for funding sources to cover their financing needs. Managers prefer internal to external financing, and, when internal funds are inadequate, debt financing is preferred to equity financing. Various empirical studies also have provided evidence that is consistent with managers' pecking order preference. ${ }^{1}$

A more controversial question is what drives the pecking order. Myers (1984) suggested that the pecking order preference arises because of the information asymmetry problems between firms and the capital market; subsequent work has provided mixed evidence of this view (e.g. Frank and Goyal, 2003; Helwege and Liang, 1996; Leary and Roberts, 2005; Shyam-Sunder and Myers, 1999). Recent theoretical proposals have advanced alternative explanations of the pecking order such as agency costs (e.g., Myers, 2003), taxes (e.g., Hennessy and Whited, 2005), and managerial optimism (e.g., Heaton, 2002). However, the corresponding tests have yet to be explored, as noted in the most recent survey by Frank and Goyal (2005). In a somewhat similar influential field study, Graham and Harvey (2001) provided some supporting evidence of the pecking order, arguing that "the preference [of the survey executives] for pecking-order-like behavior might be driven by managerial optimism" (p. 219).

This paper attempts to fill a gap in the literature by testing managerial optimism (which describes a manager's subjective belief that a firm's future performance is brighter than it actually is) as an alternative explanation for pecking order preference. We use financial data to examine empirically the extent to which managerial optimism provides a satisfactory explanation for external financing decisions. To the best of our knowledge, this paper is the first empirical study outside the United States to focus on the relation between managerial optimism and financing decisions.

Our testing is based on Heaton's (2002) theoretical work, which shows that pecking order preference can be induced by managerial optimism. The rationale for pecking order preferences depends on the extent of the undervaluation by the market from the managers' perspective. The required returns of risky securities reflect the capital market's expectation of good versus bad firm performance. Optimistic managers, however, systematically overestimate the probability of good firm performance compared with the capital market's outlook and perceive that the market undervalues their firms. Riskier securities are more sensitive to managers' probability beliefs and thus, tend to be more undervalued by the market. Therefore, optimistic managers prefer to rely on internal funding rather than issue risky security to finance their needs. When these internal funds are not forthcoming, they choose debt financing first over equity and, eventually, exhibit a pecking order preference in the financing policies.

We use a specification developed by Shyam-Sunder and Myers (1999) to test pecking order preference by examining the sensitivities between net debt issues and financing deficits, defined as real investments and dividend commitment less internal funds. The driving force now becomes managerial optimism. We conduct comparative tests to see whether the pecking order hypothesis performs better in the case of optimistic managers. The testable hypothesis, therefore, is whether

\footnotetext{
${ }^{1}$ For example, tests of capital structure theory (e.g., Fama and French, 2002; Frank and Goyal, 2005; Friend and Lang, 1988; Rajan and Zingales, 1995; Titman and Wessels, 1988) have typically found that profitable firms, which have more internal funds, use less leverage. Studies that provide more direct evidence (e.g., Lemmon and Zender, 2004; ShyamSunder and Myers, 1999) have also found that managers' choice of financing method are consistent with the pecking order.
} 
the sensitivities of the debt issues in regard to financing deficits for optimistic managers are larger than those for non-optimistic managers.

For the identification of the managers' optimism, we follow $\mathrm{Lin}, \mathrm{Hu}$, and Chen (2005) to construct a measure of optimism mainly from management earnings forecasts. We classify each manager in our sample as optimistic if the number of the manager's overestimated forecasts is greater than the number of underestimated forecasts. In using earnings forecasts, we assume that when managers are optimistic in their assessment of future outcomes, they will be more likely to provide a forecast that is overestimated (i.e., above the actual earnings). An important merit of the management earnings forecasts is their prevalence. In most countries, earnings forecasts are allowed and legislatively regulated, and the data are typically available in public. Thus, the measure constructed from such earnings forecasts could be similarly established across these countries.

A possible shortcoming of our measure is that managers may have reasons other than optimism to deliberately bias their forecasts. To address this concern, we choose listed Taiwanese companies because we have access to detailed data, which allow us to exclude from our sample forecasts that may be contaminated by incentive effects such as stock offerings, financial distress, and insider trading. As an additional robustness check, we construct an alternative measure of managerial optimism using their shareholdings, based on the assumption that optimistic managers will increase their equity positions to benefit from expected future gains. This alternative measure gives similar empirical results with the forecast measure.

Overall, our empirical results are consistent with the findings of Heaton (2002) and Graham and Harvey (2001). We find that the net-debt-issue/financing-deficit sensitivities for optimistic managers are larger than those for non-optimistic managers. This result remains robust after controlling for the effects of the specific industries and the conventional variables used in Rajan and Zingales (1995) and Frank and Goyal (2003). Namely, we find that optimism, indeed, exerts an impact on managers' financing decisions.

The remainder of this paper is organized as follows. In Section 2 we describe the pecking order preference tests through the net-debt-issue/financing-deficit sensitivity, our empirical methodology, and the sample. The empirical results are presented in Section 3. In Section 4 we provide some further robust evidence and discuss the caveats of the optimism measures. Section 5 concludes with a summary.

\section{Methodology and sample}

\subsection{Testing the pecking order through the net-debt-issue/financing-deficit sensitivity}

In this paper we apply Shyam-Sunder and Myers's (1999) methodology to test Heaton's (2002) model. We start by using financing deficit as a proxy for firms' financing needs. From the accounting cash flow identity, the financing deficit for firm $i$ in fiscal year $t\left(\mathrm{DEF}_{i t}\right)$ is defined as

$$
\mathrm{DEF}_{i t} \equiv \operatorname{Div}_{i t}+I_{i t}+\Delta W_{i t}-C_{i t}=\Delta D_{i t}+\Delta E_{i t},
$$

where Div is the cash dividend payments, $I$ is the net investment, $\Delta W$ is the change in working capital, $C$ is the operating cash flows after interest and taxes, $\Delta D$ is the net debt issues (i.e., debt issuance-debt reduction), and $\Delta E$ is the net equity issues (i.e., equity issuance-stock repurchase). ${ }^{2}$ A positive financing deficit $(\mathrm{DEF}>0)$ indicates that the internal funds are exhausted. By contrast, when the firm has a surplus, the financing deficit is negative $(\mathrm{DEF}<0)$.

\footnotetext{
${ }^{2}$ All variables are described in the Appendix.
} 
Shyam-Sunder and Myers (1999) suggested that the pecking order hypothesis can be tested through a regression of the net debt issues on the financing deficits:

$$
\Delta D_{i t}=\beta_{1}+\beta_{2} \mathrm{DEF}_{i t}+e_{i t} .
$$

The slope coefficient $\beta_{2}$ represents the net-debt-issue/financing-deficit sensitivities and indicates the extent to which new debt issues are explained by financing deficits. Shyam-Sunder and Myers (1999) argued that when firms follow the pecking order to cover their financing needs, debt issue is preferred to equity and a unity slope coefficient should be observed. In a sample of 157 large U.S. firms, they also found strong evidence that "pecking order is an excellent firstorder descriptor of corporate financing behavior" (p. 242).

\subsection{Hypothesis and empirical specification}

Heaton's (2002) model predicts that optimistic managers will choose debt financing first, as internal funds are exhausted. The driving force now becomes managerial optimism. Subsequently, if we compare the financing behaviors of optimistic and non-optimistic managers, we expect that the pecking order preference will be more prevalent among optimistic managers. Therefore, we formulate the following hypothesis:

Hypothesis. The sensitivities between net debt issues and financing deficits are larger for optimistic managers than those for non-optimistic managers.

It is noteworthy that when the firms have surplus, whether optimistic managers will first repurchase equity or pay off debt is not clear. On the one hand, because riskier securities are more undervalued by the market, optimistic managers should be inclined to repurchase them. On the other hand, optimistic managers should seek to reduce their reliance on external funds in the future and, thus, will retain cash flow or avoid high debt levels by paying off debt. Therefore, given a negative financial deficit, the difference in the net-debt-issue/financing-deficit sensitivities between optimistic and non-optimistic managers may be absent. To sum up, ceteris paribus, differences in the net-debtissue/financing-deficit sensitivities between optimistic and non-optimistic managers will be distinguishable when firms have financing needs but may be absent when the firms record a surplus.

After classifying whether managers are optimistic (as discussed in the next section), we run the following regression on the entire sample:

$$
\Delta D_{i t}=\beta_{1}+\beta_{2} \mathrm{DEF}_{i t}+\beta_{3} O_{i}+\beta_{4} \mathrm{DEF} \cdot O_{i}+\beta_{5} X_{i t}+e_{i t},
$$

where $O$ is a dummy variable (i.e., the optimism measure described in the next section), which is 1 if the manager is classified as optimistic and zero otherwise; and $X$ is the conventional set of explanatory variables proposed in the earlier literature for additional controls. $X$ includes two kinds of explanatory variables. First, to account for the potential effects of specific industries, we use two-digit industry classification codes (as given by the regulatory agency) to assign firms to 19 industries and include 18 industry dummy variables in the regressions as control variables. Second, we follow Rajan and Zingales (1995) and Frank and Goyal (2003) to attach the variables that include the tangibility of assets, market-to-book ratio, log sales, and profitability. As proposed in capital structure theories, these variables are able to explain the amount of leverage. Because the dependent variable is the change in the amount of leverage, we follow Frank and Goyal (2003) to take these variables in first differences. The coefficient $\beta_{2}$ represents the net-debtissue/financing-deficit sensitivities of non-optimistic managers, and the sum of the coefficients $\beta_{3}$ 
and $\beta_{4}$ represents the sensitivities of optimistic managers. We expect that the sensitivities of optimistic managers will be larger than those of non-optimistic managers. That is, the difference in sensitivities between optimistic managers and non-optimistic managers, $\beta_{4}$, is positive.

To avoid the possible distortion caused by firm size discrepancy, we normalize the variables related to the financing deficit by using net assets, defined as total book assets minus liabilities used for transaction purposes. As Rajan and Zingales (1995) suggested, some liabilities such as accounts payable are for trade credit rather than for financing purposes. Normalization by using net assets rather than total book assets precludes the influence of liabilities for transaction purposes. To ensure robustness, as in Frank and Goyal (2003) and most conventional capital structure tests, we also test alternative two specifications: (a) the variables are normalized by total book assets, and (b) the dependent variables are measured as the change in debt ratio (long-term debt/market value of assets and long-term debt/total book assets). The results are similar. To conserve space, we present the only results of net assets in later sections. ${ }^{3}$

Given that our sample pools cross-sectional with time-series data, changes in debt can also be affected by macro factors not contained in our empirical model. Thus, in addition to ordinary least squares (OLS) regressions, we use two other approaches to estimate the coefficients: panel regressions with yearly fixed and random effects, and average point estimates from year-by-year cross-sectional regressions and the time-series standard errors of the average point estimates to draw inferences - initiated by Fama and French (2002) and following the spirit of Fama and MacBeth (1973). These different approaches give rise to similar conclusions.

\subsection{Data description}

Our sample is made up of companies listed on the Taiwan Stock Exchange and the over-thecounter market, which are included in the Taiwan Economic Journal database. We collect the data required in this study from yearly financial statements covering the period from 1989 to 2004 . We choose 1989 as our starting year because it is the first year in which cash flow statements started to include all the required variables. Firms in the financial industries or with fiscal years ending in months other than December are excluded. To avoid survivorship bias (e.g., Kothari et al., 1995), we remove data prior to a firm's initial public offering and include all delisted firms.

The context of our managerial optimism measure involves management forecasts for earnings before tax. The data forecasts are point estimates for annual earnings and contain both mandatory forecasts from 1991 and voluntary forecasts from 1985. The former are required by the regulatory agency, and the latter are disclosed by firms through the media. ${ }^{4}$ We assume that when optimistic managers report - whether they are required or do so voluntarily - they will systematically overestimate the firms' future performance. We retain both mandatory and voluntary forecasts in our sample. ${ }^{5}$ The forecasts are also required to be released before the last day of the current fiscal year.

\footnotetext{
${ }^{3}$ All the results not reported in this paper are available from the authors.

${ }^{4}$ Legislation covering statements of the quantitative forecasts was established in 1991 (and abolished in 2002) and required that a company publicizes a prospectus containing an estimate of profits for reasons such as an equity offering, a merger or acquisition, and the acquisition or the disposition of major assets.

5 Another reason we use both voluntary and mandatory forecasts is because neither of the forecasts is immune from the endogeneity issue in our identification process (see Section 4.4: Caveats of the Optimism Measures). As a consequent, we have no reason to expect that using only the mandatory or the voluntary forecasts will make smaller the measurement error, and we choose to use both forecasts to keep the final sample as large as possible. In our untabulated test, we also use only the voluntary forecasts or the mandatory forecasts to construct our optimism measure and rerun the main regression specifications to ensure that our findings are not driven by this choice. The results are similar.
} 
Table 1

Number of management forecasts in the optimism identification process and the regression analysis

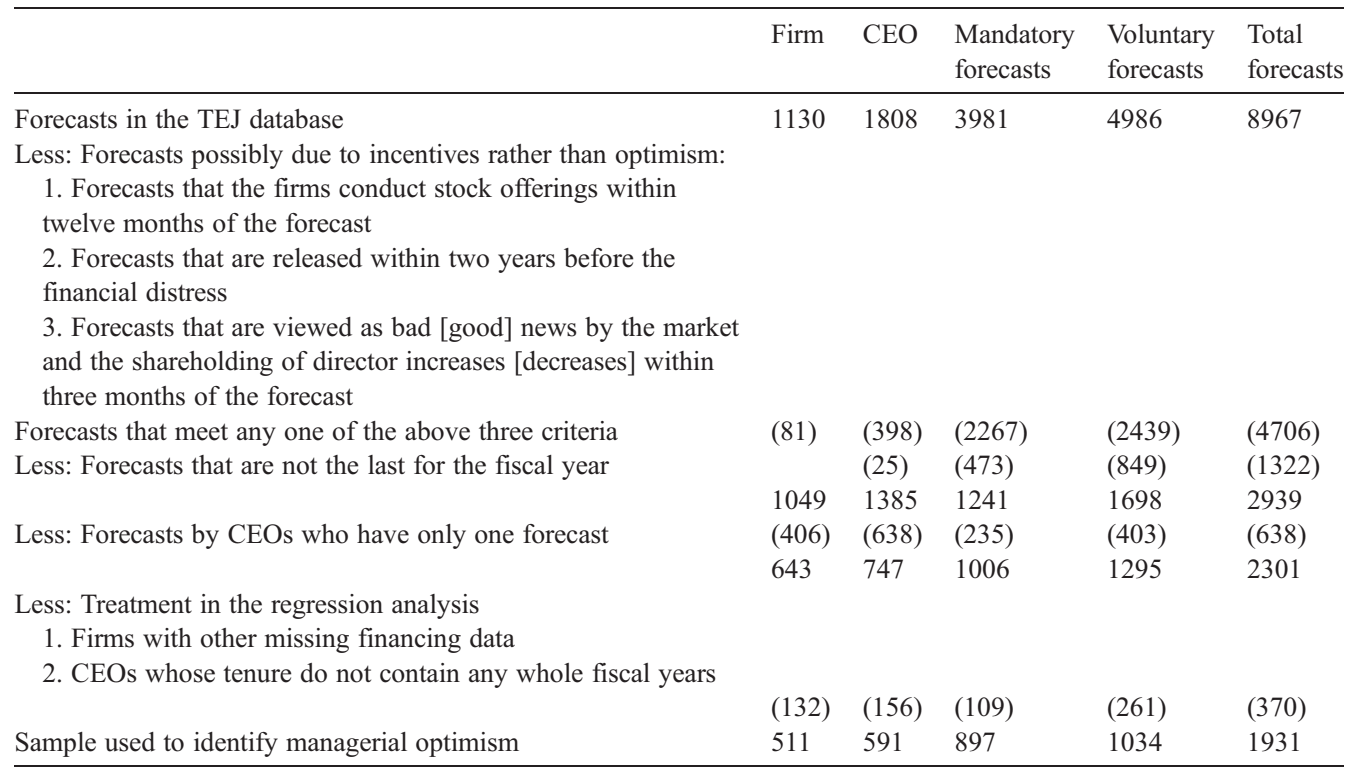

We examine the optimistic behavior of chief executive officers (CEOs) specifically. Because the forecasts in the database are attributed to the whole management team rather than a specific publisher, we assume that the forecasts are made by CEOs. The regulatory agency, the Securities and Futures Bureau, requires a monthly report from companies on shareholdings by directors at the end of the previous month; we can identify the CEO within the period by referring to the monthly directors' shareholdings data. We match the monthly directors' shareholdings with the data forecasts, identify whether the CEOs are optimistic (as examined in the following discussion), and then link the optimism measures to firms' financing data.

\subsection{Managerial optimism measure}

Based on the assumption that a CEO's optimism in assessing a future outcome is likely to lead to a forecast above actual earnings, we define a forecast error (FE) as the difference between the CEO's forecast and actual (or realized) earnings:

$$
\mathrm{FE} \equiv \mathrm{CEO}^{\prime} \mathrm{s} \text { forecast value }- \text { Actual (or realized) value. }
$$

We regard a forecast as overestimated (underestimated) if the forecast error is positive (negative) and classify the CEOs' optimism in the sample based on the relative frequency of overestimated forecasts compared with underestimated forecasts.

However, a major concern of the classification is the evidence presented in the earlier accounting literature that CEOs may have incentives other than optimism to make forecasts above or below actual earnings. To minimize the measurement error, we follow Lin, Hu, and Chen (2005) to exclude forecasts that may be contaminated by potential incentives before seeking to identify optimism. First, to launch equity offerings at a favorable price, managers 
may temporarily boost the stock price prior to the issuance by releasing overestimated forecasts. We regard forecasts as possibly tainted by managers' incentives for stock offerings if managers disclose forecasts within 12 months prior to the equity offerings. Second, due to employment concerns, managers of financially distressed firms may release overestimated forecasts prior to the distress to mislead investors. We collect data on which firms experience financial distress events (as given by the Taiwan Economic Journal) and interpret the forecasts as possibly the result of managers' incentives if the forecast is released within 2 years prior to the distress.

Third, managers may act in their own self-interest to profit from trading. In particular, they may publish overestimated (underestimated) forecasts, and then sell (buy) shares within a short period. To detect whether a forecast may be trading-motivated, we collect information on expected earnings and month-end directors' shareholdings. If a forecast is lower (higher) than what the market expected and the company directors increase (decrease) their shareholdings within 3 months of the forecast, we assume that the forecast is trading-motivated and omit it from our sample. "Expected earnings" is defined as the latest forecast available from either management or analysts for that fiscal year. If no such forecasts are available, we use the actual earnings of the previous year as the market expectations. Finally, managers may first release overestimated forecasts deliberately to give investors an overly optimistic view of the firms' prospects, and then revise the forecasts downwards later in the fiscal year to avoid punishment. We examine only the last forecast for a fiscal year after discarding the forecasts that may be contaminated by the three aforementioned potential incentives.

Table 1 describes the number of earnings forecasts in the optimism identification process and the subsequent regression analysis. We start with 8967 forecasts. Among these forecasts about $44 \%$ are mandatory, and the other $56 \%$ are voluntary. After accounting for forecasts that may be contaminated by incentives related to stock offerings, financial distress, and insider trading, we eliminate 4706 forecasts. Of these lost forecasts, $26.65 \%$ are for stock offerings, $20.57 \%$, financial distress; and $52.78 \%$, insider trading. ${ }^{6}$ About $73 \%$ of the lost forecasts because of insider trading result from selling motivation. After the last-forecast filter we retain 2939 forecasts published by 1385 different CEOs, and the percentage of mandatory forecasts is very similar to that of the starting sample. We also observe that the forecasts eliminated in the process are, on average, more overestimated than those remaining. The mean normalized (by total assets at the fiscal year end) forecast errors are 3.10\% and 1.07\% (untabulated) for the initial 8967 forecasts and the remaining 2939 forecasts, respectively.

We now identify the sample CEOs' optimism through the forecasts that do not reflect incentives. For each CEO who has at least two forecasts during his or her tenure, we calculate the percentage of his or her forecasts that are overestimated. We then define a CEO as being optimistic if the percentage is equal to or larger than $50 \%$. We remove from the sample CEOs with only one forecast to minimize the possibility that a CEO is misclassified as being optimism when, in fact, he or she overestimates for some other transitory reason or simply by chance. Among the 1385 CEOs with forecasts that do not reflect incentives, 638 CEOs have only one forecast and are excluded from the analysis. We are, thus, able to classify 747 CEOs by means of the remaining 2301 forecasts. In the later regression analysis, we further lose some observations. Finally, we analyze a sample of 591 CEOs with 1931 forecasts.

\footnotetext{
${ }^{6}$ The percentages are approximate because the elimination process is sequential. However, note that, among the three incentives, insider trading causes the most eliminations.
} 
Panel A of Table 2 shows the summary statistics of the firm data. During the sample period, the average amount of the financing deficits is New Taiwan $\$ 598.27$ million. Among the different components of Eq. (1), investment is the major source of the deficits, and the needs are primarily covered by net debt issues. After normalization, these results are similar. By examining the average normalized fund flows over time during period from 1989 to 2004 in Panel B; we find that the average deficits rise gradually prior to 2000 and then decline after 2001. A possible explanation is related to the economic trend. In Taiwan, the growth rate of the gross domestic product after 2001 is the lowest in our sample period. ${ }^{7}$ During the recession, firms have a lower working capital, invest less, distribute more cash to investors, and raise less funds through external financing. Both the net debt and the net equity issues also reach a local peak during the period from 1997 to 2000. The average of the net equity issues is larger than that of the net debt issues in earlier periods. However, the importance of the net debt relative to the net equity issues grows over time. After 2001, the average of the net equity issues reduces to only approximately one-fifth of the average net debt issues.

Given the prediction that the behavior of optimistic CEOs with a surplus is not clear, in Panel C of Table 2 we split the overall sample into two subsamples: approximately $64 \%$ in which the financial slack is exhausted and $36 \%$ in which the CEOs have a surplus. At first glance, the importance of debt relative to equity use seems to be understated without the division. In the first two columns the absolute value of the average net debt issues is much larger than that of the average net equity issues. When CEOs must cover their financing needs, on average, 62\% $(=0.0949 / 0.1532)$ of the deficits are met by debt issues. With a surplus, CEOs tend to reduce their reliance on external funds in the future by paying off debt and even issuing some equity. This observation regarding surpluses may be at least partially explained by legislation as Taiwanese companies were not allowed to repurchase their own shares until late in the year 2000. Nevertheless, CEOs' attitudes regarding the surplus remain after the repurchase is allowed. Although the average deficit is -0.560 (untabulated), the average net debt issues and the average net equity issues are -0.522 and -0.038 , respectively, for the period after 2001.

Panel D of Table 2, which reports the CEOs' classification results, shows that over $70 \%$ of CEOs are classified as optimistic- and most CEOs display optimism at all levels of forecasts rather than just at the lower forecast levels. As the CEOs may be identified optimistic with only two forecasts, the result partially alleviates the concern that having only two forecasts may still not be large enough to conclude that a CEO is optimistic, because the forecasts errors may be random rather than reflecting a CEO's behavioral trait. We discuss the low-cutoff issue in more detail in Section 4.

\section{Empirical results}

We now turn to our main focus: the relation between the managerial optimism and financing behavior. Table 3 shows the main results. Panel A divides the samples according to the extent of the managerial optimism and shows that the importance of debt relative to equity use is more pronounced for the optimistic CEOs. For all samples, in the first two columns, the ratios of net debt issues to total external financing are $53 \%$ and $49 \%$ for the optimistic and the nonoptimistic CEOs, respectively. For the observations in which the financial slack is exhausted, in

\footnotetext{
${ }^{7}$ The yearly average growth rates of GDP during the $1989-2000$ and $2001-2004$ periods are $6.43 \%$, and $2.69 \%$, respectively.
} 
the next two columns, the ratios of net debt issues to total external financing increase to $63 \%$ and $60 \%$, respectively. When a surplus exists, the behavior of the optimistic CEOs is more likely to reduce the reliance on the external funds in the future. The results in the two far-right columns show that, on average, the optimistic CEOs issue, whereas the non-optimistic retire, some equity. However, given such a tiny amount of the absolute value of the average net equity issues relative to the net debt issues, as well as the silent prediction, the comparison among the surpluses should not be overly emphasized.

Panel B presents the slope coefficients of the OLS regression results for net debt issues only in relation to financing deficits, as used in Shyam-Sunder and Myers (1999) and Frank and Goyal (2003). The first column shows that for the overall sample the slope coefficient or, equivalently, the net-debt-issue/financing-deficit sensitivity is 0.44 . By comparing optimistic with non-optimistic CEOs, we see a relation between managerial optimism and corporate external financing decisions. For the optimistic and the non-optimistic CEOs the sensitivities are 0.45 and 0.39 , respectively. When overall sample is partitioned into two subsamples in the second column according to the sign of the financing deficits, given the positive deficits, the coefficients are 0.35 and 0.29 for the optimistic and the non-optimistic CEOs, respectively. These results suggest that to cover their financing needs optimistic CEOs tend to issue more debt than non-optimistic CEOs.

In Panel C of Table 3, we statistically test for the difference in the slope coefficients between optimistic and non-optimistic CEOs through Eq. (3). In the first two columns, for both the overall sample and the positive-deficit subsample, the OLS coefficients on the interaction between the financing deficit and the optimism dummy variable- or, in terms of the differences of the slope coefficients, between optimistic and non-optimistic CEOs-are 0.06 and significant at the $1 \%$ level. All results thus far are consistent with the hypothesis.

Regarding conventional control variables, we find that the coefficients are statistically insignificant for tangibility and log sales. This result echoes the small degree of consensus on the correlation of the explanatory variables with leverage in the literature. According to Harris and Raviv (1991), tangibility may have either a positive or negative correlation with the leverage ratio. From the point of view of information asymmetry, firms with few tangible assets have greater information asymmetry problems, tend to issue more debt, and become more highly leveraged. An alternative view, based on the agency costs of debt, predicts that firms with more tangible assets will take on more debt. Lenders will incur fewer agency costs of debt and will prefer to supply loans when firms have more tangible assets. The prediction of log sales, which proxies for firm size, is also ambiguous. Size may be an indicator of information asymmetry, because small firms suffer larger information costs and tend to issue more debt. On the other hand, size may also be an inverse indicator of the bankruptcy probability and positively related to debt issues.

On the contrary, the coefficients are significantly negative in regard to the market-to-book ratio and profitability. The former result is consistent with Myers (1977), who argued that firms expecting high future growth- or, equivalently, have high market-to-book ratios - should retain the ability to seize opportunities to pay off current debt. This latter result reconciles with the pecking order hypothesis in that, when profitability exists, firms prefer to finance their activities with internal funds rather than by taking on more debt. ${ }^{8}$ In columns 4 to 6 of Table 3 , Panel C,

\footnotetext{
${ }^{8}$ Another conflicting view on the effects of profitability is mentioned by Jensen (1986), who predicted a positive effect if the market is effective in corporate control and firms are forced to issue debt to commit toward paying out cash.
} 
we include the macro factors seen through the panel regressions with yearly fixed and random effects as well as the approach proposed in Fama and French (2002). We find that the results are similar for all the estimation methods.

Finally, in the rightmost column of Panel B of Table 3, we find that for the negative-deficit subsample, the slope coefficients are unanimously close to unity, regardless of whether CEOs are optimistic. The difference in the slope coefficients between optimistic and non-optimistic CEOs in the third column of Panel $\mathrm{C}$ is -0.01 and insignificant. The legislative restriction for shares

Table 2

Summary statistics, 1989-2004

\begin{tabular}{lrrrrr}
\hline Variable & Mean & Median & SD & Minimum & Maximum \\
\hline Panel A. Full sample $(N=2997)$ & & & & & $317,384.95$ \\
Book value of total assets & $12,023.22$ & 5090.21 & $25,188.93$ & 343.80 & $164,657.19$ \\
Book value of debt & 5143.90 & 1885.08 & $11,464.18$ & 47.55 & $34,409.86$ \\
Net debt issues & 379.84 & 30.00 & 2064.43 & $-13,579.56$ & $37,035.71$ \\
Net equity issues & 218.43 & 0.00 & 1362.96 & -4599.64 & $68,940.55$ \\
Financing deficit (DEF) & 598.27 & 73.92 & 2775.88 & $-11,840.97$ & $11,904.02$ \\
Cash dividends & 164.62 & 7.01 & 621.46 & 0.00 & $20,517.18$ \\
$\Delta$ Working capital & 119.15 & 27.05 & 1157.41 & $-10,975.62$ & $84,398.10$ \\
Investments & 1059.87 & 257.36 & 3741.87 & -7106.00 & $57,085.79$ \\
Internal cash flow & 745.36 & 213.20 & 2813.31 & $-9,906.15$ & 2.2414 \\
Net debt issues/net assets & 0.0404 & 0.0101 & 0.1386 & -0.4535 & 1.2125 \\
Net equity issues/net assets & 0.0375 & 0.0000 & 0.1585 & -0.1583 & 3.7752 \\
Financing deficit/net assets & 0.0778 & 0.0234 & 0.2135 & -0.3953 & 0.2882 \\
Cash dividends/net assets & 0.0158 & 0.0020 & 0.0262 & 0.0000 & 1.7321 \\
$\Delta$ Working capital/net assets & 0.0200 & 0.0079 & 0.1375 & -4.0947 & 3.4679 \\
Investment/net assets & 0.1107 & 0.0705 & 0.1738 & -0.3246 & 0.6135 \\
Internal cash flow/net assets & 0.0686 & 0.0629 & 0.1398 & -3.6605 & 0.9641 \\
Debt ratio & 0.3945 & 0.3920 & 0.1553 & 0.0208 & 19.8597 \\
Log sales & 14.9784 & 14.8722 & 1.2247 & 9.4251 \\
Market-to-book & 1.6363 & 1.3754 & 1.0534 & 0.2796 & 7.6922 \\
Tangibility & 0.3386 & 0.3308 & 0.1942 & 0.0012 & 0.9716 \\
Return on assets & 0.0441 & 0.0441 & 0.0762 & -0.3902 & 0.7561 \\
& & & & &
\end{tabular}

Panel B. Average corporate normalized fund flows over time

\begin{tabular}{|c|c|c|c|c|}
\hline & $1989-1992(N=224)$ & $1993-1996(N=611)$ & $1997-2000(N=905)$ & $2001-2004(N=1257)$ \\
\hline Cash dividends & 0.0157 & 0.0125 & 0.0102 & 0.0213 \\
\hline$\Delta$ Working capital & 0.0194 & 0.0400 & 0.0279 & 0.0047 \\
\hline Investments & 0.1349 & 0.1318 & 0.1424 & 0.0732 \\
\hline Internal cash flow & 0.0886 & 0.0773 & 0.0553 & 0.0703 \\
\hline Financing deficit (DEF) & 0.0814 & 0.1070 & 0.1251 & 0.0290 \\
\hline Net debt issues & 0.0231 & 0.0507 & 0.0600 & 0.0243 \\
\hline Net equity issues & 0.0583 & 0.0563 & 0.0652 & 0.0047 \\
\hline Total external financing (=DEF) & 0.0814 & 0.1070 & 0.1251 & 0.0290 \\
\hline
\end{tabular}

Panel C. Average corporate normalized fund flows, by the sign of financing deficits (DEF)

\begin{tabular}{lllr}
\hline & All $(N=2997)$ & DEF $\geq 0(N=1912)$ & DEF $<0(N=1085)$ \\
\hline Net debt issues & 0.0404 & 0.0949 & -0.0557 \\
Net equity issues & 0.0375 & 0.0583 & 0.0007 \\
Total external financing (=DEF) & 0.0778 & 0.1532 & -0.0550 \\
\hline
\end{tabular}


Table 2 (continued)

\begin{tabular}{|c|c|c|c|c|}
\hline \multicolumn{5}{|c|}{ Panel D. Percentage of optimistic CEOs by number of CEO forecasts } \\
\hline $\begin{array}{l}\text { No. of CEO } \\
\text { forecasts }\end{array}$ & $\begin{array}{l}\text { No. of } \\
\text { CEOs }\end{array}$ & $\begin{array}{l}\text { No. of optimistic } \\
\text { CEOs }\end{array}$ & $\begin{array}{l}\text { No. of non-optimistic } \\
\text { CEOs }\end{array}$ & $\begin{array}{l}\% \text { of optimistic } \\
\text { CEOs }\end{array}$ \\
\hline 2 & 235 & 198 & 37 & 84.26 \\
\hline 3 & 179 & 123 & 56 & 68.72 \\
\hline 4 & 75 & 60 & 15 & 80.00 \\
\hline 5 & 45 & 34 & 11 & 75.56 \\
\hline$\geqq 6$ & 57 & 45 & 12 & 78.95 \\
\hline Total & 591 & 460 & 131 & 77.83 \\
\hline
\end{tabular}

In Panel A variables from book value of total assets to internal cash flow are in million of New Taiwan dollars. Panel B presents average corporate fund flows in a form of Eq. (1),

$$
\mathrm{DEF}_{i t}=\mathrm{Div}_{i t}+I_{i t}+\Delta W_{i t}-C_{i t}=\Delta D_{i t}+\Delta E_{i t}
$$

over time; all the variables are normalized by the net assets. Panel $\mathrm{C}$ splits the overall sample into two subsamples: (a) observations in which the financial slack is exhausted $(\mathrm{DEF}>0)$ and $(\mathrm{b})$ observations in which the CEOs have a surplus $(\mathrm{DEF}<0)$. In Panel D we identify whether a CEO is optimistic if he or she has at least two forecasts and if the percentage of the CEO's overestimated forecasts is equal to or larger than $50 \%$. See the Appendix for definitions of the variables.

repurchase in Taiwan can account for only part of the result. In an untabulated test we also use the subsample after the repurchase is allowed (i.e., after 2001). The results are similar. In short, the differences in the sensitivities between optimistic and non-optimistic CEOs are mainly related to the behaviors exhibited to cover financing needs. Because the evidence supporting our hypothesis is similar for both the overall sample and the positive-deficit subsample, to conserve space, we report only the results for the overall sample hereinafter.

\section{Discussion of the measure of managerial optimism}

A main concern for our results is that the optimism measure is improper. Therefore, in this section we provide further evidence to ensure validity and then discuss the caveats of using the optimism measure.

\section{Notes to Table 3:}

The sample period is 1989 to 2004. Panel A divides the samples according to the sign of financing deficits (DEF) and the extent of the managerial optimism. In Panels B and C the dependent variable is the net debt issues scaled by net assets. In Panel B the independent variable is the normalized financing deficits; but the intercept coefficients are suppressed to save space. In Panel C, the independent variables are the normalized financing deficits, optimism measure, the interaction of the normalized financing deficit and the optimism measure, and the conventional set of explanatory variables (i.e. Eq. (3)). Sample firms are classified as 19 industries according to their two-digit industry classification codes. Eighteen industry dummy variables are included in the regression as additional control variables, but the corresponding coefficients are suppressed to save space. The definitions of all variables are found in the Appendix. The alternative hypothesis is that in Panel B, in the first column for the entire sample and the third column for the positive-deficit subsample, the coefficients on the financing deficit are larger for optimistic CEOs than non-optimistic CEOs; or except the column in Panel C, the coefficients on the interaction of the financing deficit and the optimism measure are positive. Except the rightmost column of Panel C, $t$-statistics are reported in parentheses. $* * *, * *$, and * respectively denote significant levels at $1 \%, 5 \%$, and $10 \%$. In the rightmost column of Panel C, the regressions are run for each year from 1989 to 2004 (16 years). The regression coefficients are the means of those across years. The $t$-statistics in parentheses are defined as the mean divided by the standard error, the time series stand deviation of the regression coefficient divided by four. The critical $t$-value, proposed in Fama and French (2002, p.12 footnote 1), is adjusted with first-order autocorrelation from 1.96 to make inferences. ${ }^{\mathrm{a}}$ Denotes the significance of the coefficient; that is, the absolute value of $t$-statistic is larger that of the adjusted critical $t$-value. 
Table 3

Test of the net-debt-issue/financing-deficit sensitivities difference between optimistic CEOs and non-optimistic CEOs

Panel A: Average corporate normalized fund flows for observations, by the sign of financing deficits and the extent of managerial optimism

\begin{tabular}{|c|c|c|c|c|c|c|}
\hline & \multicolumn{2}{|c|}{ Full sample $(n=2997)$} & \multicolumn{2}{|c|}{$\mathrm{DEF} \geq 0 \quad(n=1912)$} & \multicolumn{2}{|c|}{$\mathrm{DEF}<0(n=1085)$} \\
\hline & $\begin{array}{l}\text { Optimistic } \\
\text { CEOs } \\
(n=2122)\end{array}$ & $\begin{array}{l}\text { Non-optimistic } \\
\text { CEOs }(n=875)\end{array}$ & $\begin{array}{l}\text { Optimistic } \\
\text { CEOs } \\
(n=1383)\end{array}$ & $\begin{array}{l}\text { Non-optimistic } \\
\text { CEOs }(n=529)\end{array}$ & $\begin{array}{l}\text { Optimistic } \\
\text { CEOs } \\
(n=739)\end{array}$ & $\begin{array}{l}\text { Non-optimistic } \\
\text { CEOs }(n=346)\end{array}$ \\
\hline Net debt issues & 0.0444 & 0.0307 & 0.0997 & 0.0824 & -0.0592 & -0.0484 \\
\hline Net equity issues & 0.0396 & 0.0323 & 0.0597 & 0.0547 & 0.0020 & -0.0019 \\
\hline $\begin{array}{l}\text { Total external } \\
\quad \text { financing }(=\mathrm{DEF})\end{array}$ & 0.0840 & 0.0630 & 0.1594 & 0.1372 & -0.0572 & -0.0503 \\
\hline $\begin{array}{l}\text { Net debt } \\
\text { issues/DEF (\%) }\end{array}$ & 52.86 & 48.73 & 62.55 & 60.06 & 103.50 & 96.22 \\
\hline
\end{tabular}

Panel B. Slope coefficients of OLS regressions: net debt issues on financing deficits (DEF), by the sign of the financing deficits and the extent of managerial optimism

\begin{tabular}{|c|c|c|c|c|c|c|}
\hline & \multicolumn{2}{|c|}{ Full sample $(n=2997)$} & \multicolumn{2}{|c|}{$\mathrm{DEF} \geq 0(n=1912)$} & \multicolumn{2}{|c|}{$\mathrm{DEF}<0(n=1085)$} \\
\hline & Coefficient & $R^{2}$ & Coefficient & $R^{2}$ & Coefficient & $R^{2}$ \\
\hline All CEOs & $0.44 * * *$ & 0.44 & $0.33 * * *$ & 0.30 & $0.97 * * *$ & 0.73 \\
\hline Optimistic CEOs & $0.45^{* * *}$ & 0.47 & $0.35^{* * *}$ & 0.33 & $0.96 * * *$ & 0.67 \\
\hline $\begin{array}{l}\text { Non-optimistic } \\
\text { CEOs }\end{array}$ & $0.39 * * *$ & 0.38 & $0.29 * * *$ & 0.23 & $0.98 * * *$ & 0.92 \\
\hline
\end{tabular}

Panel C. Coefficients of regressions of the sensitivities between net debt issues, optimism measure, and financing deficits (DEF), controlling for conventional variables and macro effects

\begin{tabular}{|c|c|c|c|c|c|c|}
\hline & $\begin{array}{l}\text { Full sample: } \\
\text { OLS } \\
\text { Regressions }\end{array}$ & $\begin{array}{l}\mathrm{DEF} \geq 0: \text { OLS } \\
\text { Regressions }\end{array}$ & $\begin{array}{l}\text { DEF }<0: \\
\text { OLS } \\
\text { Regressions }\end{array}$ & $\begin{array}{l}\text { Full sample: } \\
\text { yearly fixed } \\
\text { effects }\end{array}$ & $\begin{array}{l}\text { Full sample: } \\
\text { yearly random } \\
\text { effects }\end{array}$ & $\begin{array}{l}\text { Full sample: } \\
\text { avg. of cross- } \\
\text { sectional } \\
\text { regressions }\end{array}$ \\
\hline Intercept $(\times 100)$ & $\begin{array}{l}2.13 \\
(1.55)\end{array}$ & $\begin{array}{l}4.32 * * * \\
(7.28)\end{array}$ & $\begin{array}{l}0.07 \\
(0.30)\end{array}$ & $\begin{array}{l}4.90 * * * \\
(3.20)\end{array}$ & $\begin{array}{l}2.01 \\
(1.43)\end{array}$ & $\begin{array}{l}1.66 \\
(1.44)\end{array}$ \\
\hline DEF & $\begin{array}{l}0.40 * * * \\
(22.70)\end{array}$ & $\begin{array}{l}0.29 * * * \\
(12.74)\end{array}$ & $\begin{array}{l}0.98 * * * \\
(31.14)\end{array}$ & $\begin{array}{l}0.40 * * * \\
(22.91)\end{array}$ & $\begin{array}{l}0.40^{* * *} \\
(22.88)\end{array}$ & $\begin{array}{l}0.56^{\mathrm{a}} \\
(28.79)\end{array}$ \\
\hline $\begin{array}{l}\text { Optimism measure } \\
\qquad(\times 100)\end{array}$ & $\begin{array}{l}-0.01 \\
(-0.02)\end{array}$ & $\begin{array}{l}0.05 \\
(0.94)\end{array}$ & $\begin{array}{l}-0.47 \\
(-1.64)\end{array}$ & $\begin{array}{l}-0.10 \\
(-0.22)\end{array}$ & $\begin{array}{l}-0.06 \\
(-0.14)\end{array}$ & $\begin{array}{l}-0.11 \\
(-0.23)\end{array}$ \\
\hline $\begin{array}{l}\text { DEF } \times \text { Optimism } \\
\text { measure }\end{array}$ & $\begin{array}{l}0.06^{* * * *} \\
(2.96)\end{array}$ & $\begin{array}{l}0.06^{* * *} \\
(2.58)\end{array}$ & $\begin{array}{l}-0.01 \\
(-0.32)\end{array}$ & $\begin{array}{l}0.07^{* * *} \\
(3.34)\end{array}$ & $\begin{array}{l}0.06^{* * * *} \\
(3.22)\end{array}$ & $\begin{array}{l}0.03^{\mathrm{a}} \\
(3.26)\end{array}$ \\
\hline$\Delta$ Tangibility $(\times 100)$ & $\begin{array}{l}3.62 \\
(1.16)\end{array}$ & & & $\begin{array}{l}3.95 \\
(1.26)\end{array}$ & $\begin{array}{l}3.80 \\
(1.22)\end{array}$ & $\begin{array}{l}8.58 \\
(1.97)\end{array}$ \\
\hline $\begin{array}{l}\Delta \text { Market-to-book } \\
\quad(\times 100)\end{array}$ & $\begin{array}{l}-0.94 * * * \\
(-5.25)\end{array}$ & & & $\begin{array}{l}-1.09^{* * *} \\
(-5.54)\end{array}$ & $\begin{array}{l}-1.01 * * * \\
(-5.37)\end{array}$ & $\begin{array}{l}-1.94^{\mathrm{a}} \\
(-4.63)\end{array}$ \\
\hline$\Delta$ Log sales $(\times 100)$ & $\begin{array}{l}0.73 \\
(1.46)\end{array}$ & & & $\begin{array}{l}0.60 \\
(1.20)\end{array}$ & $\begin{array}{l}0.63 \\
(1.25)\end{array}$ & $\begin{array}{l}2.05^{\mathrm{a}} \\
(2.42)\end{array}$ \\
\hline$\Delta$ Profitability $(\times 100)$ & $\begin{array}{l}-0.09 * * * \\
(-2.91)\end{array}$ & & & $\begin{array}{l}-0.10 * * * \\
(-3.18)\end{array}$ & $\begin{array}{l}-0.10 * * * \\
(-3.11)\end{array}$ & $\begin{array}{l}-0.04 \\
(-0.73)\end{array}$ \\
\hline$R^{2}$ & 0.46 & 0.31 & 0.74 & 0.47 & 0.46 & \\
\hline$N$ & 2997 & 1912 & 1085 & 2997 & 2997 & \\
\hline
\end{tabular}




\subsection{Robustness of the main measure}

\subsubsection{Include forecasts prior to equity issues}

As we exclude forecasts that may be contaminated by effects such as stock offering incentive in constructing the measure, one may argue that CEOs using equity financing and with fewer forecasts may be excluded in the analysis and the main results may be due to this treatment of the data. In Panel A of Table 4, we repeat our research methodology by including these forecasts that were excluded in the Section 2. Under this treatment, an additional 75 (untabulated) CEOs are included. The number of the firm-year observations increases from 2997 to 3252, whereas the percentage of the observations with optimistic CEOs is reduced slightly from $70.80 \%(=2122$ / 2997 ) to $69.96 \%$ (=2275/3252). Compared with Table 3, in the first column of Panel A, the OLS coefficient on the financing-deficit, which represents the sensitivity for non-optimistic CEOs, decreases to 0.35 . The difference in the net-debt-issue/financing-deficit sensitivities between optimistic and non-optimistic CEOs (the coefficients on the optimism measure/financing-deficit interaction) increases to 0.14 .

We argue that if optimistic CEOs use more debt financing than non-optimistic CEOs, as predicted by Heaton (2002), excluding forecasts that actually reflect the managerial optimism due to the concern related to the stock offering incentive will be more likely to remove the nonoptimistic CEOs from the regression analysis. Subsequently, the sensitivity for non-optimistic CEOs observed in Table 3 would be larger than that in Panel A of Table 4; and the difference in the sensitivities between optimistic and non-optimistic CEOs in Table 3 would be smaller than that in Panel A of Table 4. Overall, results in Panel A of Table 4 suggest that the main finding of this paper is not due to the treatment of the data.

\subsubsection{Removing contemporaneous forecasts}

The optimism measure used as independent variable is defined using the whole sample period, which implies that the optimism is fixed over time. However, some literature has argued that managerial optimism may be time-varying. For example, in their recent paper, Billett and Qian (2006) provided evidence that the source of managers' optimism in the acquisitions activities may be developed through experience.

To tackle this concern, we modify the definition of our optimism measure. In Table 3, the optimism measure as defined using the whole sample period overlaps with the dependent variable. In Panel B of Table 4, we separate the period of forecasts used to measure optimism from that in the regressions by removing the contemporaneous forecasts. In particular, for each observation in the regression, which stands for the behavior of a CEO in a single year $t$, we define corresponding optimism using that CEO's forecasts in a non-overlapping period with a 1-year gap (i.e., prior to year $t-1)$. Subsequently, for a CEO's financing behaviors during two different periods, the corresponding managerial optimism for that CEO may differ. Note that this treatment is also able to alleviate partially the concern of the potential endogeneity (as discussed in Section 4.4 in more detail); that is, after making financing decisions, CEOs may become optimistic for whatever reason and disclose overestimated forecasts. The downside of the treatment is that using less qualified forecasts to classify CEOs decreases the sample size and enlarges the measurement error. However, although the number of firm-year observations declines from 2997 to 1111, results in Panel B of Table 4 still show that the coefficients of the interaction term are significantly positive for all estimation methods.

In Panel B of Table 4, we also observe that the coefficients of the financing deficit are about 0.7 much larger than what we observed in Table 3. Because two differences are found between Panel 
B of Tables 4 and 3 (i.e., the definition of optimism and the sample size), we further distinguish the source by using the subsample in Panel B and the optimism definition in Table 3 . In the untabulated tests, for all estimation methods the coefficients on the financing deficit of various estimation methods range from 0.77 to $0.79 .{ }^{9}$ The result suggests that the source of the difference is the composition of the sample. In Panel B, by using periods before financing decisions to define optimism, we, in fact, require a CEO to stay on the job for at least 2 years to be included in the sample. Therefore, differences between Table 4, Panel B and Table 3 suggest that CEOs may use relatively less debt financing for a given deficit during their first few years of tenure. ${ }^{10}$ Similar evidence is also reported by Litov (2005), who argued that entrenched managers with weak shareholder rights tend to use more debt. Another possible explanation is that the labor market updates CEOs' beliefs and practices over time. Concerns over their future career prod younger CEOs to adopt more conservative behaviors such as avoiding riskier debt financing. For example, Chevalier and Ellison (1999) showed that younger American mutual fund managers adopt herding behavior due to career concern.

\subsubsection{Low-cutoff issues}

A CEO is classified as optimistic if he or she has (a) at least two forecasts and (b) overestimated forecasts by at least $50 \%$. Two low-cutoff issues arise. First, having only two forecasts may still not be large enough to conclude that a CEO is optimistic, as the forecasts errors may be random rather than reflecting the CEO's optimism. Second, the $50 \%$ criterion is somewhat arbitrary, and a CEO with close to $50 \%$ overestimated forecasts may not exhibit optimism. Subsequently, our main empirical results may mainly stem from these CEOs with very few forecasts or with close to $50 \%$ overestimated forecasts.

The results in Panel D of Table 2 show that most CEOs display optimism at all levels of forecasts and, thus, partially alleviates the concern of the two-forecast constraint. In addition, in a closer look at the distribution of the CEOs over the number of overestimated forecasts in the Panel A of Table 5, we see that for all levels the distribution of overestimated forecasts are right-skew. Most of the optimistic CEOs the percentage is far from 50\%. About 47\% (=217/460) of the optimistic CEOs have at least $80 \%$ overestimated forecasts and another $27 \%(=123 / 460)$ more than $60 \%$ (and less than $80 \%$ ) of overestimated forecasts. Thus, the results can partially resolve the concern of the $50 \%$ criterion.

In an attempt to further address the concerns, we use two approaches in the regression analysis. First, besides defining managerial optimism dichotomously, we classify the sample CEOs into five groups according to the percentages. For each group we regress the net debt issues on financing deficits and observe the coefficients on the financing deficit to see whether our main results originate from the CEOs with extreme percentages. That is, to resolve the concern of the $50 \%$ criterion, the difference of the net-debt-issue/financing-deficit sensitivities should be more pronounced between the most optimistic and the least optimistic CEOs. Second, regarding the two-forecast constraint, we identify the CEOs whenever they have more (i.e., three to six) forecasts during their tenure and then redo the first step. If our main empirical results come from just the CEOs that have fewer forecasts,

\footnotetext{
${ }^{9}$ Besides the subsample in Panel B of Table 4, we also run remaining subsamples (in Table 3 but not in Table 4, Panel B) and find that the coefficients on the financing deficit of various estimation methods range from 0.31 to 0.33 . The results are not reported here.

${ }^{10}$ We also formally test whether CEOs may exhibit lower sensitivities their early in tenure by constructing a dummy variable that equals 1 if the financing policy is observed after the third year of the CEO's tenure. The OLS coefficients are 0.36 and 0.38 , respectively, on the financing deficit and the interaction term of the financing deficit with the dummy variable.
} 
Table 4

Regressions of debt issues on financing deficits (DEF) and alternative optimism measures

\begin{tabular}{|c|c|c|c|c|}
\hline & OLS regressions & Yearly fixed effects & Yearly random effects & $\begin{array}{l}\text { Average of cross- } \\
\text { sectional regressions }\end{array}$ \\
\hline \multicolumn{5}{|c|}{ Panel A. Optimism measure constructed from forecasts containing those related to equity offerings } \\
\hline DEF & $\begin{array}{l}0.35^{* * * *} \\
(27.93)\end{array}$ & $\begin{array}{l}0.36^{* * *} \\
(28.50)\end{array}$ & $\begin{array}{l}0.36^{* * *} \\
(28.38)\end{array}$ & $\begin{array}{l}0.54^{\mathrm{a}} \\
(31.72)\end{array}$ \\
\hline $\mathrm{DEF} \times$ optimism measure & $\begin{array}{l}0.14 * * * \\
(8.87)\end{array}$ & $\begin{array}{l}0.14 * * * \\
(9.51)\end{array}$ & $\begin{array}{l}0.15^{* * *} \\
(9.30)\end{array}$ & $\begin{array}{l}0.07^{\mathrm{a}} \\
(5.99)\end{array}$ \\
\hline$R^{2}$ & 0.72 & 0.73 & 0.71 & \\
\hline$N$ & 3252 & 3252 & 3252 & \\
\hline \multicolumn{5}{|c|}{ Panel B. The period of forecasts used to measure optimism is prior to that in the regressions } \\
\hline DEF & $\begin{array}{l}0.70 * * * \\
(34.90)\end{array}$ & $\begin{array}{l}0.71^{* * *} \\
(35.26)\end{array}$ & $\begin{array}{l}0.71^{* * * *} \\
(35.24)\end{array}$ & $\begin{array}{l}0.80^{\mathrm{a}} \\
(44.85)\end{array}$ \\
\hline $\mathrm{DEF} \times$ optimism measure & $\begin{array}{l}0.06 * * \\
(2.34)\end{array}$ & $\begin{array}{l}0.06 * * \\
(2.17)\end{array}$ & $\begin{array}{l}0.06 * * \\
(2.21)\end{array}$ & $\begin{array}{l}0.03^{\mathrm{a}} \\
(2.04)\end{array}$ \\
\hline$R^{2}$ & 0.46 & 0.48 & 0.47 & \\
\hline$N$ & 1111 & 1111 & 1111 & \\
\hline \multicolumn{5}{|c|}{ Panel C. Optimism measure constructed from stockholdings } \\
\hline $\mathrm{DEF}$ & $\begin{array}{l}0.51 * * * \\
(37.44)\end{array}$ & $\begin{array}{l}0.53 * * * \\
(36.48)\end{array}$ & $\begin{array}{l}0.53 * * * \\
(36.70)\end{array}$ & $\begin{array}{l}0.58^{\mathrm{a}} \\
(39.26)\end{array}$ \\
\hline DEF $\times$ optimism measure & $\begin{array}{l}0.06^{* *} \\
(2.56)\end{array}$ & $\begin{array}{l}0.06^{* * *} \\
(2.64)\end{array}$ & $\begin{array}{l}0.06^{* *} \\
(2.61)\end{array}$ & $\begin{array}{l}0.04^{\mathrm{a}} \\
(4.77)\end{array}$ \\
\hline$R^{2}$ & 0.55 & 0.56 & 0.55 & \\
\hline$N$ & 1638 & 1638 & 1638 & \\
\hline
\end{tabular}

The sample period is 1989 to 2004 . The dependent variable is the debt issues scaled by net assets. The definitions of the variables are found in the Appendix. The independent variables are the normalized financing deficits, optimism measure, the interaction of the normalized financing deficit and the optimism measure, and the conventional set of explanatory variables (i.e., Eq. (3)). Only the coefficients on the normalized financing deficits and on the interaction of the normalized financing deficit and the optimism measure are reported here to save space. In Panel A, in the construction of the optimism measure, we do not exclude forecasts that may be contaminated by incentives for equity offerings. In Panel B, for each observation in year $t$ in the regression, we define that CEO's optimism using forecasts before year $t-1$. In Panel C, we define optimism based on the CEOs' stockholding behavior in their first 3 years in tenure but use only the CEOs' remaining year of their tenure in the regressions. Except the rightmost column of Panels A to C the $t$-statistics are reported in parentheses. $* * *, * *$, and $*$ respectively denote significant levels at $1 \%, 5 \%$, and $10 \%$. In the rightmost column of Panels A to C, the regressions are run for each year from 1989 to 2004 (16 years). The regression coefficients are the means of those across years. The $t$-statistics in parentheses are defined as the mean divided by the standard error, the time series stand deviation of the regression coefficient divided by four. The critical $t$-value is adjusted with first-order autocorrelation from 1.96 to make inferences.

${ }^{a}$ Denotes the significance of the coefficient; that is, the absolute value of $t$-statistic is larger that of the adjusted critical $t$-value.

the positive coefficient on the optimism measure/financing-deficit interaction and the positive difference of the net-debt-issue/financing-deficit sensitivities between the most optimistic and the least optimistic CEOs should be less pronounced for CEOs with more forecasts.

Panel B of Table 5 reports the results of these approaches. Results in the first row are able to further alleviate the concern of the $50 \%$ criterion. Although the OLS regression coefficient does not monotonically increase with the extent of optimism, we do observe that the coefficients for the extreme extent of optimistic CEOs support our main results. The net-debt-issue/financing-deficit sensitivity is much larger for the most optimistic CEOs group (0.51, the rightmost column) than that for the least optimistic group ( 0.27 , the leftmost column). Therefore, results in previously 
reported findings are more likely to originate from the CEOs with extreme percentages. Results in other rows are similar and also able to alleviate the concern of the two-forecast constraint. Both the positive coefficient on the optimism measure/financing-deficit interaction, and the positive difference of the net-debt-issue/financing-deficit sensitivities between the most optimistic and the least optimistic CEOs remain. Our main results seem to hold for the sample of CEOs with the most forecasts - not just for those with very few forecasts. In other words, the low-cutoff is not a critical issue.

Table 5

Test of the pecking order, regarding the low-cutoff issues

\begin{tabular}{|c|c|c|c|c|c|c|c|c|}
\hline \multirow[b]{2}{*}{ Number of CEO forecasts } & \multicolumn{8}{|c|}{ Number of overestimated forecasts } \\
\hline & 0 & 1 & 2 & 3 & 4 & 5 & $\geq 6$ & Total \\
\hline 2 & 37 & 85 & 113 & & & & & 235 \\
\hline 3 & 16 & 40 & 61 & 62 & & & & 179 \\
\hline 4 & 7 & 8 & 19 & 27 & 14 & & & 75 \\
\hline 5 & 2 & 4 & 5 & 19 & 12 & 3 & & 45 \\
\hline$\geq 6$ & 0 & 2 & 4 & 16 & 12 & 11 & 12 & 57 \\
\hline Total & 62 & 139 & 202 & 124 & 38 & 14 & 12 & 591 \\
\hline
\end{tabular}

Panel B: The net-debt-issue/financing-deficit sensitivities with an x-forecast constraint

\begin{tabular}{|c|c|c|c|c|c|c|c|}
\hline & & \multirow[b]{2}{*}{$\begin{array}{l}\mathrm{DEF} \times O \\
\text { full sample }\end{array}$} & \multicolumn{5}{|c|}{$\begin{array}{l}\text { DEF by the subsamples according to the percentage of the CEOs' overestimated } \\
\text { forecasts }\end{array}$} \\
\hline & & & $\begin{array}{l}<20 \% \text { (the least } \\
\text { optimistic) }\end{array}$ & $\begin{array}{l}{[20 \%,} \\
40 \%)\end{array}$ & $\begin{array}{l}{[40 \%} \\
60 \%)\end{array}$ & $\begin{array}{l}{[60 \%} \\
80 \%)\end{array}$ & $\begin{array}{l}\geqq 80 \% \text { (the most } \\
\text { optimistic) }\end{array}$ \\
\hline \multirow[t]{2}{*}{$x=2$} & Coefficient & 0.06 & 0.27 & 0.50 & 0.44 & 0.43 & 0.51 \\
\hline & $N$ & 2997 & 365 & 258 & 622 & 747 & 1005 \\
\hline \multirow[t]{2}{*}{$x=3$} & Coefficient & 0.28 & 0.26 & 0.50 & 0.52 & 0.43 & 0.66 \\
\hline & $N$ & 2118 & 174 & 258 & 351 & 747 & 588 \\
\hline \multirow[t]{2}{*}{$x=4$} & Coefficient & 0.16 & 0.35 & 0.62 & 0.52 & 0.66 & 0.71 \\
\hline & $N$ & 1352 & 78 & 155 & 351 & 476 & 292 \\
\hline \multirow[t]{2}{*}{$x=5$} & Coefficient & 0.34 & 0.31 & 0.49 & 0.47 & 0.70 & 0.73 \\
\hline & $N$ & 919 & 24 & 126 & 203 & 332 & 234 \\
\hline \multirow[t]{2}{*}{$x=6$} & Coefficient & 0.30 & NA & 0.31 & 0.57 & 0.61 & 0.77 \\
\hline & $N$ & 553 & 9 & 95 & 160 & 174 & 115 \\
\hline
\end{tabular}

Panel A reports the distribution of the CEOs over the number of CEOs forecasts and the number of overestimated forecasts. In Panel B, the dependent variable is the debt issues scaled by net assets. The independent variables in the "Full sample" column are the normalized financing deficits (DEF), the optimism measure $(\mathrm{O})$ described in Section 2, the interaction of the normalized financing deficit and the optimism measure, and the conventional set of explanatory variables. The independent variables in the other columns are the normalized financing deficits and the conventional set of explanatory variables. The definitions of the variables are found in the Appendix. We include a CEO in the regressions whenever he or she has at least $x$ (from 2 to 6 ) forecasts during the tenure, after eliminating forecasts that may be contaminated by incentive effects. The CEOs are then classified into five groups according to the percentage of their forecasts that are overestimated, that is, the forecast value above the actual (realized) values. The alternative hypothesis is that, for the "Full sample" column, the coefficient on the interaction of the financing deficit and the optimism measure is positive, or for the other columns, the coefficients on the financing deficit of the CEOs in the larger percentage (more optimistic) groups are larger than those in the smaller (less optimistic) ones. The "Coefficient" rows report the coefficients on the interaction of the normalized financing deficit for the "Full sample" column, and the coefficients on the normalized financing deficits for other columns. All of the reported coefficients are significant at $1 \%$. 
Table 6

The optimism measure and proxies for information asymmetry

\begin{tabular}{|c|c|c|c|c|c|c|}
\hline \multirow[t]{2}{*}{ Proxy } & \multicolumn{2}{|c|}{ Number of } & \multicolumn{2}{|c|}{ Average of } & \multirow{2}{*}{$\begin{array}{l}\text { Absolute } \\
\text { value of } \\
t \text {-statistic }\end{array}$} & \multirow[t]{2}{*}{$p$-value } \\
\hline & $\begin{array}{l}\text { Optimistic } \\
\text { CEOs }\end{array}$ & $\begin{array}{l}\text { Non-optimistic } \\
\text { CEOs }\end{array}$ & $\begin{array}{l}\text { Optimistic } \\
\text { CEOs }\end{array}$ & $\begin{array}{l}\text { Non-optimistic } \\
\text { CEOs }\end{array}$ & & \\
\hline $\begin{array}{l}\text { Firm size (millions of } \\
\text { new Taiwanese dollars) }\end{array}$ & 460 & 131 & $10,653.03$ & $11,230.22$ & 0.25 & 0.8010 \\
\hline Age (years) & 460 & 131 & 12.68 & 11.65 & 1.17 & 0.2425 \\
\hline Ownership concentration (\%) & 460 & 131 & 25.07 & 26.05 & 0.84 & 0.4039 \\
\hline Tangibility of assets (\%) & 460 & 131 & 32.41 & 32.09 & 0.19 & 0.8462 \\
\hline Number of the media tracking & 460 & 131 & 2.32 & 2.29 & 0.62 & 0.5328 \\
\hline Forecast dispersion of the media $(\%)$ & 436 & 122 & 5.46 & 6.00 & 0.59 & 0.5529 \\
\hline Dividend payout $(\%)$ & 460 & 131 & 36.31 & 38.41 & 0.95 & 0.3441 \\
\hline
\end{tabular}

The table presents the results of the tests of whether the CEOs classified as optimistic face a larger information asymmetry problem. We apply seven proxies for information asymmetry: firm size, age, ownership concentration, tangibility of assets, number of the media tracking the company, forecast dispersion of the media, and dividend payout (see the Appendix for definitions). For each of the CEOs during the tenure, we collect the firms' age and the ratio of cash-dividend years and calculate the averages of firm size, ownership concentration, tangibility of assets, number of the media tracking the company, and forecast dispersion of the media. We then compute the averages of optimistic CEOs and non-optimistic CEOs. The null hypothesis is that for each proxy, the average number of optimistic CEOs equals that of non-optimistic CEOs.

\subsection{Is our measure a proxy for information asymmetry?}

Prior literature has argued that information asymmetry problems also have an impact on the debt use and the net-debt-issue/financing-deficit sensitivities. Because the information asymmetry problems between the firms and the investors can be eliminated by earnings forecasts, the potential contemporaneous correlation between the forecasts and the information asymmetry problems cannot be ignored. In this case, a risk exists that the optimism measure constructed through these forecasts is related to information asymmetry problems. As a consequence, the significance of the optimism measure/financing-deficit interaction coefficients may, in fact, be a result of information asymmetry rather than optimism.

We use some firm characteristics tied to problems of information asymmetry such as firm size, age, ownership concentration, tangibility of assets, number of the media tracking the firm, forecast dispersion of the media forecasts, and dividend payout to observe whether the CEOs classified as optimistic face larger information asymmetry problems. ${ }^{11}$ We collect the firms' listed dates and the ratio of cash-dividend years, and calculate the averages of the yearly book assets, the monthly shareholding rate of the directors, the yearly tangibility, the yearly number of the media tracking, and the yearly forecast dispersion of the media for each of the CEOs during their tenure. Then we compute the averages of optimistic CEOs and of non-optimistic CEOs. If the optimism measure is related to information asymmetry, the CEOs classified as optimistic should have lower asset values, younger ages, less concentrated ownership, less tangible, less media attention, more dispersed media-forecast, and lower dividends (i.e., firms with larger information asymmetry problems), and

\footnotetext{
${ }^{11}$ For data limitations, characteristics related to the media attempt to capture the spirits of those related to the analysts (for an excellent review of the literature of the information asymmetry problems and management and analysts' forecasts, see Healy and Palepu, 2001). Number of the media tracking is the number of the media that ever published their expectations, according to the analysts' forecasts, on the firm's earnings during the fiscal year. Forecast dispersion is the standard deviation of the forecast error of the last forecast of the media for the fiscal year.
} 
Table 7

OLS regression analysis of the sensitivities between net debt issues, proxies for information asymmetry, and financing deficits (DEF)

\begin{tabular}{|c|c|c|c|c|c|c|c|}
\hline & Firm size & Age & $\begin{array}{l}\text { Ownership } \\
\text { concentration }\end{array}$ & $\begin{array}{l}\text { Tangibility } \\
\text { of assets }\end{array}$ & $\begin{array}{l}\text { Number of } \\
\text { the media } \\
\text { tracking }\end{array}$ & $\begin{array}{l}\text { Forecast } \\
\text { dispersion } \\
\text { of the media }\end{array}$ & $\begin{array}{l}\text { Dividend } \\
\text { payout }\end{array}$ \\
\hline Intercept $(\times 100)$ & $\begin{array}{l}0.74 * * * \\
(2.67)\end{array}$ & $\begin{array}{l}-0.22 \\
(-0.79)\end{array}$ & $\begin{array}{l}0.24 \\
(0.84)\end{array}$ & $\begin{array}{l}0.11 \\
(0.39)\end{array}$ & $\begin{array}{l}1.08 * * * \\
(3.56)\end{array}$ & $\begin{array}{l}1.62 * * * \\
(3.73)\end{array}$ & $\begin{array}{l}0.15 \\
(0.54)\end{array}$ \\
\hline Financing deficit & $\begin{array}{l}0.52 * * * \\
(42.98)\end{array}$ & $\begin{array}{l}0.60 * * * \\
(30.37)\end{array}$ & $\begin{array}{l}0.51 * * * \\
(38.89)\end{array}$ & $\begin{array}{l}0.50 * * * \\
(33.16)\end{array}$ & $\begin{array}{l}0.48 * * * \\
(34.03)\end{array}$ & $\begin{array}{l}0.50 * * * \\
(25.70)\end{array}$ & $\begin{array}{l}0.58 * * * \\
(32.99)\end{array}$ \\
\hline $\begin{array}{l}\text { Information asymmetry } \\
\text { dummy variable }(\times 100)\end{array}$ & $\begin{array}{l}-0.40 \\
(-1.03)\end{array}$ & $\begin{array}{l}1.28 * * * \\
(3.24)\end{array}$ & (1.25) & $(2.04)$ & $\begin{array}{l}-1.03 \\
(-2.59)\end{array}$ & $\begin{array}{l}-1.08^{*} \\
(-1.78)\end{array}$ & $\begin{array}{l}0.32 \\
(0.79)\end{array}$ \\
\hline $\begin{array}{l}\text { Financing deficit } \times \\
\text { information asymmetry } \\
\text { dummy variable }\end{array}$ & $-0.17^{* * *}$ & $-0.20^{* * *}$ & $-0.13^{* * *}$ & $-0.09^{* * *}$ & $-0.06^{* * *}$ & $(-1.23)$ & $-0.13^{* * *}$ \\
\hline$\Delta$ Tangibility $(\times 100)$ & $\begin{array}{l}1.64 \\
(0.54)\end{array}$ & $\begin{array}{l}4.10 \\
(1.35)\end{array}$ & $\begin{array}{l}3.86 \\
(1.26)\end{array}$ & $\begin{array}{l}3.62 \\
(1.17)\end{array}$ & $\begin{array}{l}3.51 \\
(1.14)\end{array}$ & $\begin{array}{l}4.85 \\
(1.01)\end{array}$ & $\begin{array}{l}7.85 * * \\
(2.39)\end{array}$ \\
\hline$\Delta$ Market-to-book $(\times 100)$ & $\begin{array}{l}-0.80 * * * \\
(-4.54)\end{array}$ & $\begin{array}{l}-0.86^{* * *} \\
(-4.85)\end{array}$ & $\begin{array}{l}-0.96 * * * \\
(-5.40)\end{array}$ & $\begin{array}{l}-0.90 * * * \\
(-5.03)\end{array}$ & $\begin{array}{l}-0.94 * * * \\
(-5.33)\end{array}$ & $\begin{array}{l}-0.77 * * * \\
(-3.25)\end{array}$ & $\begin{array}{l}-1.13 * * * \\
(-6.12)\end{array}$ \\
\hline$\Delta$ Log sales $(\times 100)$ & $\begin{array}{l}0.52 \\
(1.08)\end{array}$ & $\begin{array}{l}0.66 \\
(1.35)\end{array}$ & $\begin{array}{l}0.68 \\
(1.40)\end{array}$ & $\begin{array}{l}0.69 \\
(1.41)\end{array}$ & $\begin{array}{l}0.78 \\
(1.60)\end{array}$ & $\begin{array}{l}0.20 \\
(0.32)\end{array}$ & $\begin{array}{l}0.37 \\
(0.75)\end{array}$ \\
\hline$\Delta$ Profitability $(\times 100)$ & $\begin{array}{l}-0.10^{* * *} \\
(-3.21)\end{array}$ & $\begin{array}{l}-0.08^{* * *} \\
(-2.72)\end{array}$ & $\begin{array}{l}-0.08 \\
(-2.80)\end{array}$ & $\begin{array}{l}-0.09^{* * *} \\
(-2.86)\end{array}$ & $\begin{array}{l}-0.09 * * * \\
(-2.81)\end{array}$ & $\begin{array}{l}-0.09^{* *} \\
(-2.15)\end{array}$ & $\begin{array}{l}-0.02 \\
(-0.71)\end{array}$ \\
\hline$R^{2}$ & 0.48 & 0.47 & 0.46 & 0.46 & 0.46 & 0.46 & 0.51 \\
\hline$N$ & 2997 & 2997 & 2997 & 2997 & 2997 & 1396 & 2997 \\
\hline
\end{tabular}

The sample period is from 1989 to 2004 . The dependent variable is the debt issues scaled by net assets. The independent variables are the normalized financing deficits, dummy variable for information asymmetry, the interaction of the normalized financing deficit and the information asymmetry dummy variable, and the conventional set of explanatory variables. Sample firms are classified as 19 industries according to their two-digit industry classification codes. Eighteen industry dummy variables are included in the regression as additional control variables, but the corresponding coefficients are suppressed to save space. For each year, we sort the firms into two groups respectively according to firm size, ownership concentration, tangibility, and the number of the media tracking and define information asymmetry dummy variables, which are equal to 1 if the firms are subject to have more severe information asymmetry problems (e.g., smaller $50 \%$ firms); and zero otherwise. For the proxies age and dividend payout, we defined the dummy variable as equal to 1 for the younger $50 \%$ or the smaller $50 \%$ cash-dividend-year ratio, and zero otherwise. All the definitions of variables are found in the Appendix. The alternative hypothesis is that the coefficient on the interaction of financing deficit and the optimism measure is positive. $t$-statistics are reported in parentheses. $* * *, * *$, and $*$, respectively, denote significant levels at $1 \%$, $5 \%$, and $10 \%$.

we should observe a significant difference between the averages of optimistic CEOs and of nonoptimistic CEOs. For instance, if optimistic CEOs bear a larger information asymmetry problem, the average firm size of optimistic CEOs should be significantly smaller than that of non-optimistic CEOs. Results in Table 6, however, do not support this conjecture. Given all of these characteristics, none exhibit a significant difference between optimistic and non-optimistic CEOs.

To further consider the concern of the relation between debt use and information asymmetry problems, we also apply the regression specification of Eq. (3) to the previously defined firm characteristics. In particular, according to information asymmetry assumptions, the pecking order theory should perform better for firms with more severe information asymmetry problems. For each characteristic, we sort our final sample into two groups: one group more likely to have severe information asymmetry problems; and the other, less. We define a dummy variable that equals 1 for 
the group of larger information asymmetry problems, and zero for the other group. We then compare the net-debt-issue/financing-deficit sensitivities of the two groups through regressing the debt issues on the interaction term of the financing deficit with the information asymmetry dummy variable. In Table 7, we observe that for six of the seven characteristics the coefficients on the interaction term are negative and significant at a $1 \%$ level. The result is contrary to information asymmetry assumptions, and, subsequently, our main results of the significant relation between the managerial optimism and the debt use in our final sample are less likely due to the information asymmetry.

\subsection{An alternative measure based on CEOs' shareholding change}

To further substantiate our use of earnings forecasts as a measure of optimism, we also measure optimism based on changes in CEOs' shareholdings. CEOs are exposed to their firms' idiosyncratic risk. Their personal wealth, reputation, and employability are linked to their firms' performance; however, CEOs cannot hedge their risk by their companies' short-selling stocks. Therefore, Malmendier and Tate (2005) argued that CEOs should minimize their holdings of company stock. CEOs who are optimistic about future outcomes will repeatedly increase their equity positions early in their tenure to benefit from expected future gains.

Empirically, a measure based on stockholdings requires a sufficiently long tenure for the CEO and a properly defined term early in tenure. Because the median of the tenure are about 5 years (62 months), we confine our sample to CEOs having at least 5 years tenure at a listed company and use 3 years as the basis for the early in tenure designation. Specifically, we use CEOs' stockholding rates for their first 3 years in tenure to define optimism. ${ }^{12}$ After computing the CEOs' average yearly dividend-adjusted shareholding rates for their first 3 years of tenure, we classify them as optimistic if their average shareholding rates increase for at least 2 years. We then use only the CEOs' remaining year of their tenure to estimate Eq. (3). Among the 591 sample CEOs, 253 remain in the regressions, and about $55 \%$ of these remaining CEOs are identified as optimistic. The correlation of the measure from forecasts with that from stockholdings is positive, although fairly weak (.09). We also find, in Panel $\mathrm{C}$ of Table 5, that the significance of the coefficients on the interaction term remains for all the estimation methods. The result is still similar for the optimism measure from stockholdings. ${ }^{13}$

\subsection{Caveats of the optimism measures}

Despite our efforts to address some concerns regarding the robustness of our results, the optimism measures do, indeed, have their own imperfections. In the following we discuss the limitations of the measures.

\footnotetext{
${ }^{12}$ Stock option grants do not affect the calculation here for two reasons. First, the number of option grants in hand reflects compensations decided by the board of directors rather than CEOs themselves. Second, Taiwanese companies were not allowed to issue employee stock options until 2001 ("Regulations Governing the Offering and Issuance of Securities by Securities Issuers"). Given that the end of our sample period is 2004, the vesting restrictions naturally separate the option grants from the stock purchases in looking at CEO shareholdings.

${ }^{13}$ Similar with the optimism measure from earnings management, there is a potential low-cutoff drawback that increasing only 2 years may still not be longer enough to conclude that a CEO is optimistic. In untabulated tests, instead of defining managerial optimism dichotomously, we classify the 253 CEOs into four groups according to the number of years CEOs' shareholdings increase and regress the net debt issues on financing deficits and observe the coefficients on the financing deficit. The results show that the significance of the coefficients on the interaction term comes mainly from the extreme groups. Furthermore, we also require the CEOs to have tenure of more than $x$ (from 6 to 8 ) years and use $x-2$ years as the basis for the early in tenure designation at a downside of fewer observations, the results are similar.
} 
For the main measure based on earnings forecasts, a caveat related to the analysis is the endogeneity issue. As we have identified some sources for overestimated forecasts and excluded them from the sample, it is likely that some forecasts are still incentive-driven rather than revealing managers' true optimism. The data forecasts contain both mandatory and voluntary forecasts, and neither is immune from the endogeneity issue in our identification process. On one hand, as a general rule, any voluntary managerial action may be subject to a systematic reason, and an unidentified systematic reason may exist for managers to overestimate earnings. On the other hand, mandatory actions are usually free of the systematic reason. However, because managers are required to issue earnings forecasts to the public before specific corporate events, the concern that CEOs deliberately inflate the forecasts for self-interest remains. In other words, despite our efforts, it is unlikely that we can capture all the incentive-driven forecasts and fully rule out the endogeneity issue.

For the measure constructed according to shareholding change, we caution that, similar to forecasts, the CEOs' equity holding change may be also a result of reasons other than their optimism. For example, CEO's selling company stocks may be viewed as a bad signal of firm prospects and, thereby, the CEO's reputation. Consequently, the career concern implicitly restricts the CEO from reducing the shareholding. Once the CEO gets equity-based compensation, the CEOs' shareholding may even increase. Alternatively, CEOs' not selling company stocks may be due to their insider information about firms' good prospects. Overall, optimism may account for only part of the effect on the shareholding change, thus measurement errors may still occur.

\section{Conclusions}

Despite the influence of the pecking order theory on corporate finance theories, recent literature has indicated that besides the information asymmetry problems, an alternative source may be managerial optimism. Heaton (2002) theoretically showed that managerial optimism is also able to lead to managers' pecking order preference. We empirically test Heaton's argument and explore the extent to which managerial optimism provides a satisfactory explanation for the financing decisions of listed Taiwanese firms.

Given the difficulty in identifying a proper proxy for managerial optimism in carrying out the empirical research, the evidence related to managerial optimism is rare. As in Lin et al. (2005), we use a measure of optimism from firms' earnings forecasts to test the theoretical predictions for the behaviors of optimistic managers. To avoid a misidentification due to other incentives, we first carefully eliminate biased forecasts that may be contaminated by effects such as stock offerings, financial distress, and insiders' trading and then construct the optimism measure. The optimism measure is helpful to test the theoretical predictions for the behaviors of optimistic managers, however, we caution that the measure suffers from endogeneity. The forecasts used to identify optimism are still likely incentive-driven.

Focusing on whether pecking order preference performs better for optimistic managers, we apply the Shyam-Sunder and Myers' (1999) approach and regress the net debt issues on the financing deficit, the optimism measure, and the interaction of optimism and the financing deficit. To the extent that the measure is valid, we find a strong positive relation between the sensitivity of net debt issues to financing deficits and managerial optimism. That is, the sensitivities between the net debt issues and financing deficits for optimistic managers are larger than those for nonoptimistic managers. The result is very robust and confirms the role of managerial optimism in corporate financing decisions. Compared with prior evidence that correlates pecking order preference with information asymmetry, this paper makes a contribution by providing evidence that CEO optimism is an alternative source that drives pecking order preference. 


\section{Appendix A. Variable definitions}

\begin{tabular}{|c|c|}
\hline Variable name & Definition \\
\hline \multicolumn{2}{|l|}{ Measure of optimism } \\
\hline $\begin{array}{l}\text { Measure of optimism constructed from } \\
\text { management earnings forecasts }\end{array}$ & $\begin{array}{l}\text { Dummy variable equals to } 1 \text { for a CEO if the percentage of his or her } \\
\text { overestimated forecasts during the tenure is equal to or larger than } 50 \% \text {. }\end{array}$ \\
\hline Overestimated & Forecast error is positive. \\
\hline Forecast error & CEO's forecast for earnings before tax - Actual earnings before tax \\
\hline $\begin{array}{l}\text { Measure of optimism constructed } \\
\text { from stockholdings }\end{array}$ & $\begin{array}{l}\text { Dummy variable equals to } 1 \text { for the CEOs if they have been in their position } \\
\text { for at least } 5 \text { years and if their average dividend-adjusted shareholding rates } \\
\text { increase for at least two of the first three years in tenure. }\end{array}$ \\
\hline \multicolumn{2}{|l|}{ Measure of optimism } \\
\hline Dividend-adjusted shareholdings & Shares adjusted for earning reserve and capital reserve \\
\hline \multicolumn{2}{|c|}{ Test for optimism measures and external financing decisions } \\
\hline Net debt issues $(\Delta D)$ & Increase (decrease) short-term debt + increase (decrease) long-term debt \\
\hline Net equity issues $(\Delta E)$ & Proceed new issue + decrease (increase) treasury stocks \\
\hline Financing deficit (DEF) & Cash dividends + net investment + change in working capital - internal cash flow \\
\hline Cash dividends (Div) & Dividends paid + director and employee bonus paid \\
\hline Net investment $(I)$ & $\begin{array}{l}\text { Sale (purchase) short-term investment (investment purpose) }+ \text { decrease (increase) } \\
\text { of derivative for investment }+ \text { sale long-term investment }+ \text { purchase long-term } \\
\text { investment }+ \text { Sale fixed assets }+ \text { purchase fixed assets }+ \text { cash paid-merging }\end{array}$ \\
\hline Change in working capital $(\Delta W)$ & $\begin{array}{l}\text { Decrease (increase) in } \mathrm{A} / \mathrm{R} \text { and } \mathrm{N} / \mathrm{R}+\text { decrease (increase)-inventories + other } \\
\text { adjustment operating + change in cash and cash equivalents }\end{array}$ \\
\hline Internal cash flow $(C)$ & $\begin{array}{l}\text { Net income current }+ \text { non-cash extraordinary depreciation }+ \text { depreciation }+ \\
\text { amortization }+ \text { investment income (equity method) }+ \text { investment loss (equity } \\
\text { method) }+ \text { cash dividend long-term investment }+ \text { loss (gain) disposal short-term } \\
\text { investment }+ \text { decrease (increase) short-term investment trading }+ \text { decrease } \\
\text { (increase) of derivative for trade }+ \text { loss (gain) disposal fixed assets }+ \text { loss (gain) } \\
\text { disposal Long-term investment }+ \text { provision (reversal of reserve) }\end{array}$ \\
\hline
\end{tabular}

Variable name

Definition

Test for optimism measures and external financing decisions

Tangibility of assets

$Q$

Market value of total assets

Book value of total assets

Log sales

Profitability

Net book assets

Total fixed assets/book value of total assets

Market value of total assets/book value of total assets

Market capitalization + total liabilities

Total assets

Ln [Net sales]

Return on asset (earnings before interests and depreciation)

Total assets - Total current liabilities + bill issued + short-term borrowing + current of long-term debt

\section{Proxies for information assymetry (for Tables 6 to 7)}

Firm size

Age

Ownership concentration

Tangibility of assets

Number of the media tracking

Forecast dispersion

Dividend payout
Book assets at the beginning of the fiscal year

Number of years since listed

Average of monthly shareholding rate of directors

Total fixed assets/book value of total assets

Number of the media that ever published their expectations on the firm's earnings during the fiscal year

Standard deviation of the forecast error of the last forecasts of the media for the fiscal year

The ratio of the number of years with non-zero cash dividend to the number of years in the sample period 


\section{References}

Billett, M., Qian, Y., 2006. Are overconfident CEOs born or made? Evidence of self-attribution bias from frequent acquirers. Working Paper. University of Iowa, Iowa City.

Chevalier, J., Ellison, G., 1999. Career concerns of mutual fund managers. Quarterly Journal of Economics 114, 389-431.

Fama, E., French, K., 2002. Testing trade-off and pecking order predictions about dividends and debt. Review of Financial Studies $15,1-33$.

Fama, E., MacBeth, J., 1973. Risk, return and equilibrium: empirical tests. Journal of Political Economy 81, $607-636$.

Frank, M., Goyal, V., 2003. Testing the pecking order theory of capital structure. Journal of Financial Economics 67, $217-248$.

Frank, M., Goyal, V., 2005. Tradeoff and pecking order theories of debt. In: Espen Eckbo, B. (Ed.), Handbook of Empirical Corporate Finance. Handbooks in Finance Series. Elsevier/North-Holland. Chapter 7.

Friend, I., Lang, L., 1988. An empirical test of the impact of managerial self-interest on corporate capital structure. Journal of Finance 43, 271-281.

Graham, J., Harvey, C., 2001. The theory and practice of corporate finance: evidence from the field. Journal of Financial Economics 60, 187-243.

Harris, M., Raviv, A., 1991. The theory of capital structure. Journal of Finance 46, 297-356.

Healy, P., Palepu, K., 2001. A review of the empirical disclosure literature. Journal of Accounting and Economics 31, 405-440.

Heaton, J., 2002. Managerial optimism and corporate finance. Financial Management 31, 33-45.

Helwege, J., Liang, N., 1996. Is there a pecking order? Evidence from a panel of IPO firms. Journal of Financial Economics 40, 429-458.

Hennessy, C., Whited, T., 2005. Debt dynamics. Journal of Finance 60, 1129-1165.

Jensen, M., 1986. Agency costs of free cash flow, corporate finance and takeovers. American Economic Review 76, 323-339.

Kothari, S., Shanken, J., Sloan, R., 1995. Another look at the cross-section of expected stock returns. Journal of Finance $50,185-224$.

Leary, M., Roberts, M., 2005. Financial slack and tests of the pecking order's financing hierarchy. Working Paper. Duke University, Durham, NC.

Lemmon, M., Zender, J., 2004. Debt capacity and tests of capital structure theories. Working Paper. University of Utah, Salt Lake City.

Lin, Y., Hu, S., Chen, M., 2005. Managerial optimism and corporate investment: some empirical evidence from Taiwan. Pacific-Basin Finance Journal 13, 523-546.

Litov, L., 2005. Corporate governance and financing policy: new evidence. Working Paper. Washington University.

Malmendier, U., Tate, G., 2005. CEO overconfidence and corporate investment. Journal of Finance 60, 2661-2700.

Myers, S., 1977. Determinants of corporate borrowing. Journal of Financial Economics 5, 147-175.

Myers, S., 1984. The capital structure puzzle. Journal of Finance 39, 575-592.

Myers, S., 2003. Financing of corporations. In: Constantinides, G.M., Harris, M., Stulz, R. (Eds.), Handbook of the Economics of Finance, vol. 1. Elsevier/North Holland, Amsterdam.

Rajan, R., Zingales, L., 1995. What do we know about capital structure? Some evidence from international data. Journal of Finance 50, 1421-1460.

Shyam-Sunder, L., Myers, S., 1999. Testing static tradeoff against pecking order models of capital structure. Journal of Financial Economics 32, 263-292.

Titman, S., Wessels, R., 1988. The determinations of capital structure choice. Journal of Finance 43, 1-19. 